\title{
Preference Order of Responses to Economic Distress in Italian Listed Firms
}

\author{
Pierluigi Santosuosso ${ }^{1}$ \\ ${ }^{1}$ School of Economics, Sapienza University of Rome, Rome, Italy \\ Correspondence: Pierluigi Santosuosso, School of Economics, Sapienza University of Rome, Rome, Italy. Tel: \\ 39-6-4976-6460. E-mail: pierluigi.santosuosso@uniroma1.it
}

Received: May 8, 2013

Accepted: July 9, 2013

doi: 10.5539/ibr.v6n8p1
URL: http://dx.doi.org/10.5539/ibr.v6n8p1
Online Published: July 25, 2013

\begin{abstract}
This paper examines a sample of 72 firms listed on the Italian Stock Exchange between 2007 and 2011 which were in serious economic difficulty. These companies adopted a series of measures to find a way out of the crisis, including management changes, divestment of assets, debt restructuring and the issuing of new shares. The paper aims to verify the existence of a preference order for responses to the economic crisis. Unlike previous research, a methodology has been adopted which analyses the content of the Management Commentary in order to identify both the proposals presented by managers and the measures actually adopted. The result of the analysis shows that the different types of measures to solve the crisis are often proposed and/or realized in a combined manner. Although the existence of a pecking order is not immediately obvious, a preference for management changes seems to emerge, whereas debt renegotiation and the issuing of new shares appear to be used only as secondary responses. Furthermore, based on the results of the logistic regression model, this paper suggests that the reasons for choosing the types of restructuring measures appears to be mainly related to their profitability. Managers of low profitability firms intervene most frequently on the capital structure rather than adopting general management changes and divestment plans. This result is consistent with the Pecking order theory which deals with the hierarchy of funding sources followed by firms.
\end{abstract}

Keywords: crises, economic distress, Italian firms, pecking order theory

\section{Introduction}

The global economic crisis has inevitably affected Italian firms, as shown by the negative performance of industrial production indicators. According to the Bank of Italy (Banca d'Italia, 2013), the industrial production index has decreased significantly since 2008 (from 107 in the first quarter to 93.3 in the fourth quarter of 2008) and still maintains low values compared to those of previous years (the index presented values of less than 90 in the first quarter of 2013). There has also been a decrease in profitability. According to Mediobanca (Mediobanca, 2012; Mediobanca, 2008) the return on invested capital, for a sample of over 2000 large companies, fell significantly between 2007 and 2011 (from a ROI of approximately 11\% in 2007 to 8.5\% in 2011). The intensification of the crisis can also be seen in the economic state of companies listed on the Italian Stock Exchange. As emerges from this research, a third (33.6\%) of listed companies showed a negative "net income from continuing operations" in the five-year period 2007-2011 for at least three years. The deterioration in these companies' economic situation is confirmed by the trend of the general stock price index. The FTSE Italia All-Share Index (Borsa Italiana, 2013) fell by more than fifty per cent between 2007 and 2013 (from 38.745 in December 2007 to 16.887 in February 2013).

In this situation of declining corporate performance, managers have adopted various measures to improve the economic and financial conditions of firms, as for example, by reducing the workforce, reorganizing production, changing the sales network, mergers, measures to increase efficiency and the reconstruction of bank debts or issuing of new shares. These measures have been taken voluntarily, and not as part of bankruptcy procedures, to rationalise the firms' operations and to modify their capital structure.

The purpose of this paper is to examine the choices relating to crises resolution measures proposed by managers of listed companies on the Italian Stock exchange between 2007 and 2011 in order to see whether some types of measures are preferred to others. In other words, in so far as it is possible to find an objective response, the research attempts to highlight the existence of a preference order among these measures. Furthermore, to explore 
the reasons for choosing one type of restructuring rather than another, the paper analyzes the relationship between the type of responses to the crisis and a set of financial ratios of the selected firms on the basis of the logistic regression model.

The main research question of this paper draws on the well-known debate that has developed around the Pecking order theory (POT) about financing choices. According to this theory there exists a hierarchy among the sources of funding so that firms prefer to finance through funds generated internally, then through the issuing of debt and lastly through the issuing of new shares. The POT can be an interesting point of reference since fund raising, for firms in economic and financial distress, is one of the most important questions they have to deal with.

Although the fundamental arguments of the POT are taken into account, the present study differs significantly from previous research because of the particular situation of the firms under investigation and the research methodology adopted. This article examines companies listed on the Italian Stock Exchange under economic distress and adopts a methodology research that tends to identify the managers' preferences regardless of the actual implementation of the responses to the crises using data derived from the examination of the Management Commentary section of firms' financial statement (a narrative report that jurisdictions may also define as Management's Discussion and Analysis, Management's report or Operating and Financial Review).

The article is organized as follows: the second section provides a brief review of the literature; the third section describes data and sample selection; the fourth section explains the survey methodology; the fifth section presents the results; the last section exposes the concluding remarks.

\section{Literature Review}

Choices about capital structure are widely debated in economic literature. The POT is certainly one of the best known and most significant theories developed on this issue. It postulates that firms prefer to finance new investments according to a specific hierarchical sequence, firstly through internal funds (retained earnings), then the issuing of debt and finally, as a last resort, the issuing of shares (Myers 1984; Myers \& Majluf 1984). The POT is based on the assumption that, in financial markets characterized by asymmetric information between managers and investors, the decision to issue new shares constitutes a negative signal that leads investors to depress the share price. In order to avoid the negative effects arising from this undesirable situation, such as the transfer of wealth from old to new shareholders, managers prefer to finance new investments with retained earnings. If there is an insufficient amount of internal funds, debt financing will be used so that the old shareholders are not harmed by the issuing of new shares.

The POT has been the subject of numerous empirical tests and has been received favourably in numerous works, but the analyses have not produced concordant results. The following are some of these researches which were carried out on different samples of firms. Consistent with the predictions of the POT, Baskin (1989), Allen (1993), Tong and Green (2005) found that leverage varies inversely with firm profitability. Shyam-Sunder and Myers (1999) showed that POT has a much greater explanatory power than static trade-off models, which suggests that firms adjust to an optimal debt ratio. Chirinko and Singha (2000) pointed out that their empirical analysis was not able to evaluate either the POT or static trade-off models and alternative tests were needed. In their investigation of Italian firms' capital structure, Bigelli, Mengoli and Sandri (2001) confirmed the validity of the POT on a sample of 95 firms in the years between 1992 and 1996. Fama and French (2002) could not affirm whether the results of their study on predictions about dividends and debt are due to trade-off forces, pecking order forces or indeed other factors. Frank and Goyal (2003) claimed that the POT does not provide a robust explanation for firms of all sizes. Panno (2003) examined the capital structure choices made by companies in the UK and Italy and provided evidence in support of the POT. Leary and Roberts (2005) argued that firms are not likely to finance investments with external funds when they have adequate internal funds, but they tend to appeal to the external market for large investment financing. In their analysis of information asymmetry and capital structure decisions in U.S. firms Bharath, Pasquariello and Wu (2009) highlighted the validity of the POT. Lemmon and Zender (2010) suggested that, in the absence of debt capacity concerns, debt appears to be preferred to equity. Al Manaseer et al. (2011) provided evidence for the POT against target capital structure theory in the UK market. Bauweraerts and Colot (2012) revealed that neither POT nor Static Trade-off Theory can explain why family rather than non-family firms are more likely to adopt an indebtedness target ratio. In his examination of a sample of French companies, Mazen (2012) confirmed the explanatory power of the POT.

Although the POT has been widely studied by researchers around the world and there is an extensive literature on the resolution of financial distress (Hotchkiss et al., 2008), the analysis of the POT rarely focuses on companies in economic and financial distress. As regard the firms financially distressed, Liang and Bathala (2009) verified the validity of the theory on a sample of 94 U.S. companies in financial distress between 1990 
and 2004. The results of this study, developed on the basis of the model proposed by Shyam-Sunder and Myers (1999), seem to weakly support the validity of the POT.

Studies on firms in economic distress have not received the same interest in the research literature as those in financial distress and, a fortiori, the POT has not been specifically highlighted when firms are economically distressed. John, Lang and Netter (1992) described the responses of 82 US firms to negative earnings between 1980 and 1987 and analysed changes in control, operations, investments and financial policies. Kang and Shivdasani (1997) explained the restructuring of 92 listed firms in economic distress in Japan between 1985 and 1989. Kahl (2002) described financial distress as a dynamic process, underlining the importance for creditors to discern between economically viable firms and firms that should be liquidated. Jiang and Wang (2009) conducted an empirical analysis of 300,000 Chinese firms in economic distress in order to highlight the responses for the firms' survival. On a sample of 505 firms between 1991 and 2004, Lemmon, Ma and Tashjian (2009) pointed out that, with Chapter 11 of the US Bankruptcy code, the value of financially distressed firms is preserved, whilst the assets of firms in economic distress are redeployed. Using a sample of 6,118 Belgian firms in economic distress between 1998 and 2000, Balcaen et al. (2012) examined how firms' features are related to the exit type. On a sample of 60,202 firm-year observations from Compustat between 1978 and 2000, Molina and Preve (2009) underlined that highly leveraged firms in economic distress that diminish their use of trade receivables have a sales reduction greater than firms that do not diminish that use whilst Opler and Titman (1994) pointed out the effects that leverage may have on a firm's performance in industries that have experienced economic distress.

\section{Data and Sample Selection}

The sample was constructed to include the companies listed on the Italian Stock Exchange under economic distress. Generally, economic distress refers to the company's inability to generate positive earnings. Despite the presence of valuable research on this issue (John, Lang, \& Netter, 1992; Kang \& Shivdasani, 1997; Andrade \& Kaplan 1998; Jiang \& Wang, 2009), a detailed definition of economic distress has not yet been developed. The selection of the sample therefore met with a number of problems as a result of the uncertainty about the concept.

In order to illustrate the complexity of the topic, we will briefly mention three main problems. First of all, it is not clear which indicators can help to identify the state of crisis. Economic distress can be measured through a negative trend of different results; for example, net income, the operating income, numerous ratios that are used in the financial analysis or through a fall in share value. Secondly, it is not obvious what degree of decline signifies economic distress. For example, it could be a fall in positive earnings, significant losses or a substantial fall in share values compared with the stock market trend. Lastly, it is well known that economic and financial distress are often present in unhealthy firms. Financial distress can be the cause of economic distress and vice versa or may arise as a result of separate events. Therefore, it is not clear whether the definition of economic distress should allow for the presence of financial distress or whether it would be possible to exclude companies that also show signs of financial distress. This would involve identifying the characteristics of financial distress and deciding how to proceed with the evaluation. Many studies have focused on the measurement of financial distress, but there are differing opinions and analytical techniques. The first were made by Beaver (1966) and Altmam (1968) and focused on accounting issues, whereas later studies moved on to the analyzing and forecasting of financial crises using new methodologies, as for example, artificial intelligence and neural networks (Fanning \& Cogger, 1994; Etheridge \& Sriram, 1997; Brockett et al., 2006; Wu, Liang, \& Yang, 2008). For a more extensive review of the literature see Ward (1994), Ward and Foster (1997), Hillegeist et al. (2004), Campbell, Hilscher \& Szilagyi (2010), Sheikhi et al. (2012).

In order to find companies that are in economic distress, empirical studies have adopted different criteria. John, Lang and Netter (1992) selected firms that had at least one year of negative earnings between 1980 and 1987, followed by three years of positive earnings. Kang and Shivdasani (1997) first constructed a sample of healthy firms in a particular year on the basis of two criteria: the ratio of pre-tax operating income to assets that exceeded the industry median and the ratio of operating income to interest greater than one. The sample was a subset of firms that showed a reduction of at least $50 \%$ in the pre-tax operating income in the subsequent year. Jiang and Wang (2009) include firms in their sample if their ROA (Return on Assets) was in the top three quartiles or above for at least two consecutive years and then in the bottom fourth quartile in the next year or several years. The study left out the time-series observations of a firm if its earnings before interest and tax were lower than its expenses on interest, so that companies in financial distress were excluded. In order to distinguish between financial and economic distress, Lemmon, Ma and Tashjian (2009) classified firms as economically distressed based on industry-adjusted EBITDA-to-assets. Andrade and Kaplan (1998) aimed to measure the cost of financial distress by selecting a sample of firms, with positive operating margins exceeding the industry median, 
Table 1. Sample of firms

\begin{tabular}{|c|c|c|c|c|c|c|c|c|c|c|c|}
\hline \multirow[t]{2}{*}{ Firms } & \multicolumn{5}{|c|}{ Years } & \multirow[t]{2}{*}{ Firms } & \multicolumn{5}{|c|}{ Years } \\
\hline & 2011 & 2010 & 2009 & 2008 & 2007 & & 2011 & 2010 & 2009 & 2008 & 2007 \\
\hline Acque pot. & - & - & - & - & - & Le b. società & • & - & - & - & - \\
\hline Aedes & • & - & • & • & • & $\mathrm{M} \& \mathrm{C}$ & • & & & - & • \\
\hline Aeffe & - & - & - & & & Mediac. & - & & - & • & \\
\hline Aion Ren. & - & - & - & & & Mer. Fly & • & - & - & • & • \\
\hline Alerion & - & - & • & • & & Meridie & • & - & & • & • \\
\hline Antichi Pell. & - & - & • & & & Molmed & • & • & - & • & • \\
\hline Arena & - & - & - & - & - & Mondo TV & & - & & • & • \\
\hline Bastogi & • & - & • & $\cdot$ & • & Monrif & • & $\cdot$ & & • & • \\
\hline Bee Team & & & - & - & - & Montefibre & • & & - & - & • \\
\hline Best Union & • & • & • & & & Moviemax & • & & • & - & • \\
\hline Bialetti & - & - & • & - & & Novare & & • & • & • & \\
\hline Biesse & - & - & - & & & Olidata & - & - & - & - & - \\
\hline Bioera & & - & - & - & & Pierrel & • & - & - & • & • \\
\hline Brioschi & • & • & • & & • & Pininfarina & • & • & • & • & • \\
\hline Chl & • & • & & • & • & Poligrafica & & • & • & • & $\cdot$ \\
\hline Ciccolella & • & • & $\cdot$ & • & • & Pol. Ed. & & - & - & • & - \\
\hline Cobra & - & - & - & - & & Pramac & • & - & - & & \\
\hline Crespi & • & • & • & • & & Prelios & • & • & • & $\cdot$ & \\
\hline D'amico & • & • & • & & & Ratti & & • & • & • & • \\
\hline Damiani & • & • & • & - & & $\mathrm{Rdb}$ & • & $\cdot$ & • & • & \\
\hline Dea Capital & - & - & - & - & & Retelit & - & - & - & - & - \\
\hline Eems & • & • & • & • & & Ricchetti & • & $\cdot$ & • & • & \\
\hline Ei Towers & • & & & - & • & Richard G. & • & - & - & • & • \\
\hline Ergycapital & • & - & • & - & - & Risanam. & - & • & • & - & - \\
\hline Eukedos & - & - & - & - & & Rosss & - & - & - & & \\
\hline Eurotech & - & - & - & - & - & Seat & • & - & - & • & \\
\hline Fidia & & & $\cdot$ & • & • & Sintesi & • & $\cdot$ & • & • & • \\
\hline Fullsix & • & - & • & - & - & Snai & - & - & • & • & \\
\hline Gabetti Pr. & • & - & • & - & - & Sole 24 ore & - & - & • & & \\
\hline Gemina & • & & • & • & • & Sopaf & • & • & - & & \\
\hline Ind. e Inn. & • & & • & • & & Stefanel & • & - & • & - & • \\
\hline Intek & • & - & • & • & & Tas & • & & • & • & \\
\hline Itway & & - & • & - & & Tiscali & - & - & • & • & • \\
\hline Kinexia & - & & $\cdot$ & $\cdot$ & - & Txt & • & - & • & • & • \\
\hline Kme & - & - & - & - & & Uni Land & - & - & - & - & \\
\hline Krenergy & • & • & • & • & - & Zucchi & • & & - & • & • \\
\hline
\end{tabular}

Description: sample of firms listed on the Italian Stock Exchange with a negative "net income from continuing operations" reported in their financial statements for at least three years between 2007 and 2011. (•) indicates the presence of a net negative result. 
which were financially, but not economically distressed, whereas Balcaen et al. (2011) defined economic distress as a state in which operating revenues are inadequate to cover the operating expenses, the financial costs of debt and taxes. Economic distress is also used in the economic research literature relating to the economic crises of a country or sector (Song, 2012; Boushey \& Weller, 2008; Southall \& Gilbert, 1996).

In this research the sample is composed of the firms listed on the Italian Stock Exchange (Borsa Italiana) that reported persistent losses. Irrespective of the causes, the repeated absence of profits forced managers to postpone the distribution of dividends, thus putting at risk the very existence of the company. The present research identified 72 firms matching our criteria. Table 1 lists the sample of firms.

More specifically, the sample selection was made on the basis of the following criteria.

Firms were included in the sample if, in the period 2007-2011, the "net income from continuing operations ", as shown in the Consolidated Income Statement was negative for at least three years. According to the International Financial Reporting Standard "Non-current assets held for sale and discontinued operations" (IFRS 5), the net operating income is the net income before the sum of the post-tax profit or loss of a discontinued operation and the post-tax gain or loss recorded as the measurement at fair value less costs to sell or after the disposal of the assets or disposal groups constituting the discontinued operation (Deloitte, 2008; Dezzani, Biancone, \& Busso, 2012). The net income from continuing operations allows us to consider an amount without the effects unrelated to the core business of the firm.

The choice of the time period under examination was made in order to consider the years in which companies reported significant losses, namely the years of the global economic crisis. Since 2008, as emerges from the aggregate data on the leading Italian companies, numerous firms have recorded a drop in net income (Mediobanca, 2012). As noted in the introduction, the deterioration in their performances is also confirmed by other indicators, such as the industrial production index (Banca d'Italia, 2013) and the general stock price indices of listed companies (Borsa Italiana, 2013).

The construction of the sample was made using data from Msn (2012) whilst the analysis of firms' responses to the crises was made by examining individually the Management Commentary. We excluded from the sample the banks, finance and insurance companies and firms whose financial statement in euro is not available on the corporate website. However, firms that were not only in economic, but also in financial distress, were not excluded. An efficient means of separating them would have proved difficult, especially as the deteriorating economic and financial situation was already creating significant losses.

\section{Methodology}

The empirical verification of the POT is usually based on the analysis of margins and/or the ratios calculated primarily on accounting data. Without going into a detailed analysis of the research literature, it is nevertheless worth noting the funds flow deficit computed by adding dividend payments, capital expenditures, net increase in working capital, current portion of long-term debt and subtracting the operating cash flows, after interest and taxes (Shyam-Sunder \& Myers, 1999; Chirinko \& Singha, 2000; Bauweraerts \& Colot, 2012) and the numerous indices that are used to measure a firm's level of debt or its degree of profitability (Fama \& French, 2002; Frank \& Goyal, 2003; Leary \& Roberts, 2005; Panno, 2003; Lemmon \& Zender, 2006; Bharath, Pasquariello, \& Wu, 2009; Mazen, 2012). From the analysis of these indicators the studies have tried to delineate the order of preference followed by firms for their financing.

Unlike the methodologies adopted by studies on the POT, this paper identifies the restructuring measures adopted in an economic crisis through an analysis of the Management Commentary. This is a voluntary report prepared by management that describes the performance and financial position of the firm, gives forward-looking information about both the firm and the sector and provides other supplementary and complementary information (Menicucci, 2013; Bozzolan, Trombetta, \& Beretta, 2009; IASB, 2010). Where possible, the CEO's letter to shareholders has also been examined. Management Commentary and the CEO's letter were downloaded directly from companies' websites and individually analyzed. More specifically, the analysis was made on the basis of the following criteria:

Restructuring measures are taken into consideration only if they are presented by the managers to deal specifically with the crisis facing the company. As most measures adopted by firms for restructuring in a crisis are also used frequently by healthy firms, as for example measures taken to improve efficiency or modify the financial structure, only those operations proposed and/or realised in the years under consideration that were illustrated specifically in the Management Commentary as restructuring measures were analysed. 
The restructuring measures were included regardless of how effective they were. The Management Commentary is frequently comprised of both proposals and the summary account of measures actually completed. The moment in which the restructuring measures are announced constitutes the first stage of a decision that presumably will develop into a broader time horizon, so that the operation reported in a particular year is the announcement of a future operation or that the operation is underway.

There is a twofold advantage in the analysis of the Management Commentary. First of all, this investigation enables us to observe both the restructuring programmes in times of crisis proposed by managers and the measures actually taken. Even if the measures are not followed through, the mere proposal presented in the Management Commentary still represents the decisions taken by managers. For example, numerous firms may want to restructure their debt to re-establish economic equilibrium, but their plans could be rejected by banks even before they are presented to shareholders in the Management Commentary and so the decision to restructure will not be found in the Financial and Economic Statement. Therefore, if our investigation does not reveal proposals, some of the managers' decisions will not be identified. Secondly, the analysis of the Management Commentary enables us to observe the restructuring operations directly without resorting to various types of proxies from which the firms' behaviour can be deduced. Not all proxies are able to highlight decisions about restructuring measures. For example, measures taken to increase sales revenue, such as extending the product range or re-organising the sales network, may be entirely or partially successful, but counterbalanced by an increase in costs. The analysis of the net income, operating income or other proxies may not be sufficient to identify the choices adopted by managers to restructure the firm.

The analysis of the Management Commentary obviously has some limitations. First, as often happens in qualitative estimates, there is inevitably a certain margin of error due to the analyst's judgement. This will depend on how detailed the presentation of the restructuring proposal was in the Management Commentary. In some cases the presentation is not clear, either because of its brevity or the difficulty of establishing a relationship between the economic crisis and the restructuring measures. Second, due to its narrative explanations, the Management Commentary is not sufficient to identify the reasons for choosing one type of restructuring rather than another.

In order to highlight which predictor variables can explain the choices of types of restructuring, the present work has grouped the responses to the crises into two main groups: the responses that affected only assets (Assets side) and those that occur exclusively or non-exclusively on capital structure (Debt \& Equity side). The logistic regression analysis is used in this paper involving the binary dependent variable $\mathrm{Y}$ (Assets side $\mathrm{Y}=0$; Debt \& Equity side $\mathrm{Y}=1$ ) and a set of financial ratios $x_{p}$ as independent variables: EBITDA margin (EDIBTA to Sales), Return on assets (EBIT to total assets), Return on investment (EBIT to the sum of debt and equity), Return on sales, Current ratio (current assets to current debts), Equity to Assets and Debt to Assets. These financial ratios are calculated as the mean for five years, from 2007 to 2011. Let $p=P(Y=1)$, the logistic regression model has the following general form:

$$
\operatorname{logit}(p)=\log (p /(1-p))=\beta_{0}+\beta_{1} x_{1}+\beta_{2} x_{2}+\ldots+\beta_{p} x_{p}
$$

where $\log (p /(1-p))$ is the natural logarithm of the odds, $p$ is the probability between 0 and 1 that the dependent variable will occur, $x_{p}$ is the $p t h$ explanatory (predictor) variables, $\beta_{p}$ is the $p t h$ parameters of the logistic model derived by the method of maximum likelihood.

\section{Results}

The analysis of the Management Commentary was made initially by classifying the proposed and/or completed restructuring measures in four basic types: management changes, divestment of both current and non-current assets, debt restructuring and equity issuance. Table 2 shows the result of the observations.

The management changes included the following: reduction in circulating capital, reduction in workforce through the use of the Cassa Integrazione Guadagni (Redundancy Fund), the conversion of production sites, development of the retail network, reorganisation of production, mergers and demergers, acquisitions and founding of companies, extending the product range, direct measures to modify industrial costs, reduced working hours, the conversion of the direct sales network into franchising, increasing supply to the most remunerative market segments, outsourcing of production, a re-negotiation of the distribution agreements, the introduction of instalment payments of tax arrears and measures to increase efficiency. Among the divestment of current and non-current assets we can find: the closure of factories, the sale of plants, the closure of some lines of activities, the divestment of shares, the sale of museums and art collections. Debt restructuring includes the issuing of convertible bonds, changes to financial covenants, the negotiation of new debt deadlines, the conversion of debt 
Table 2. Types of restructuring

\begin{tabular}{|c|c|c|c|c|c|c|c|c|c|c|c|}
\hline Firms & & & Years & & & Firms & & & Years & & \\
\hline & 2011 & 2010 & 2009 & 2008 & 2007 & & 2011 & 2010 & 2009 & 2008 & 2007 \\
\hline Acque pot. & M & M & M & M & M & Le b. società & & & & & M,I \\
\hline Aedes & M,I & M,I & M,I,D,E & M,I,D,E & M,I,D & $\mathrm{M} \& \mathrm{C}$ & n.a. & & & & \\
\hline Aeffe & M & M & M & & & Mediac. & & & M & $\mathrm{D}, \mathrm{E}$ & \\
\hline Aion Ren. & M,I,D,E & $\mathrm{M}, \mathrm{D}, \mathrm{E}$ & M,I,D & & & Mer. Fly & $\mathrm{M}, \mathrm{D}, \mathrm{E}$ & $\mathrm{M}, \mathrm{D}, \mathrm{E}$ & $\mathrm{M}, \mathrm{D}, \mathrm{E}$ & $\mathrm{M}, \mathrm{D}, \mathrm{E}$ & $\mathrm{M}, \mathrm{D}, \mathrm{E}$ \\
\hline Alerion & n.a. & & & & & Meridie & n.a. & & & & \\
\hline Antichi Pell. & $\mathrm{I}, \mathrm{D}$ & I,D & $\mathrm{I}, \mathrm{D}$ & & & Molmed & n.a. & & & & \\
\hline Arena & M,I,D,E & $\mathrm{M}, \mathrm{I}, \mathrm{D}, \mathrm{E}$ & $\mathrm{M}, \mathrm{I}, \mathrm{D}, \mathrm{E}$ & M,I,D,E & M,I,D,E & Mondo TV & E & & & & \\
\hline Bastogi & M & & M,I & & & Monrif & n.a. & & & & \\
\hline Bee Team & $\mathrm{E}$ & & M,I,D,E & $\mathrm{M}, \mathrm{E}$ & $\mathrm{M}, \mathrm{I}, \mathrm{D}, \mathrm{E}$ & Montefibre & M,I,D & M,I,D & M,I,D & M,I,D & M \\
\hline Best Union & n.a & & & & & Moviemax & $\mathrm{M}, \mathrm{D}, \mathrm{E}$ & M,D & M,D & M & M \\
\hline Bialetti & M,I,D & $\mathrm{I}, \mathrm{D}, \mathrm{E}$ & $\mathrm{D}, \mathrm{E}$ & M & & Novare & n.a. & & & & \\
\hline Biesse & & M & M & & & Olidata & M,D & M,D & $\mathrm{M}, \mathrm{D}, \mathrm{E}$ & M & M \\
\hline Bioera & & $\mathrm{E}$ & I & & & Pierrel & M,I,E & M,D & M,D & M & \\
\hline Brioschi & n.a. & & & & & Pininfarina & M & M,D & M,I,D,E & M,I,D,E & $\mathrm{M}, \mathrm{D}, \mathrm{E}$ \\
\hline Chl & $\mathrm{M}, \mathrm{E}$ & $\mathrm{M}, \mathrm{E}$ & M,E & M & M & Poligrafica & M & M & M & & \\
\hline Ciccolella & & & & I & & Pol. Ed. & M & M & M & & \\
\hline Cobra & $\mathrm{D}, \mathrm{E}$ & $\mathrm{M}, \mathrm{D}, \mathrm{E}$ & $\mathrm{M}, \mathrm{D}, \mathrm{E}$ & & & Pramac & M,D & M,D & M & M & \\
\hline Crespi & M,I,D,E & M,I,D,E & M,I,D & M & & Prelios & & M & $\mathrm{M}, \mathrm{E}$ & $\mathrm{M}, \mathrm{E}$ & \\
\hline D'amico & n.a. & & & & & Ratti & & $\mathrm{M}, \mathrm{D}, \mathrm{E}$ & $\mathrm{M}, \mathrm{E}$ & M & \\
\hline Damiani & M & M & M & M & & $\mathrm{Rdb}$ & $\mathrm{M}, \mathrm{D}, \mathrm{E}$ & M & M,D & M & \\
\hline Dea Capital & n.a. & & & & & Retelit & n.a. & & & & \\
\hline Eems & $\mathrm{D}$ & $\mathrm{D}$ & $\mathrm{D}$ & & & Ricchetti & M & $\mathrm{M}, \mathrm{E}$ & M & M & \\
\hline Ei Towers & n.a. & & & & & Richard G. & M,I,D & M,I,D,E & M,I,D,E & M,I,D,E & $\mathrm{M}, \mathrm{D}, \mathrm{E}$ \\
\hline Ergycapital & $\mathrm{M}, \mathrm{E}$ & $\mathrm{E}$ & & & & Risanam. & M,I,D,E & M,I,D,E & $\mathrm{M}, \mathrm{I}, \mathrm{D}, \mathrm{E}$ & M,I,D & M,I,D \\
\hline Eukedos & $\mathrm{I}, \mathrm{D}, \mathrm{E}$ & M,I,D & & & & Rosss & M,D & M,D & M,D & M & \\
\hline Eurotech & & & M & & & Seat & $\mathrm{D}$ & $\mathrm{D}$ & & & \\
\hline Fidia & & M & M & & & Sintesi & M,I,E & M,I,D,E & M,I,D & & \\
\hline Fullsix & M,I,D & M,D & M,D & M,I & & Snai & & $\mathrm{D}$ & $\mathrm{D}$ & & \\
\hline Gabetti Pr. & M,I,D,E & $\mathrm{M}, \mathrm{I}, \mathrm{D}, \mathrm{E}$ & M,I,D,E & M,I,D,E & & Sole 24 ore & M & M & M & & \\
\hline Gemina & n.a. & & & & & Sopaf & & M,I,D & M,I & M,I & M,I,D \\
\hline Ind. e Inn. & n.a. & & & & & Stefanel & M,I,D & M,I,D,E & M,I,D & $\mathrm{D}, \mathrm{E}$ & \\
\hline Intek & M & & & & & Tas & & $\mathrm{D}, \mathrm{E}$ & $\mathrm{D}$ & M,D & M,I,D \\
\hline Itway & $\mathrm{M}, \mathrm{E}$ & $\mathrm{M}, \mathrm{E}$ & M & M & & Tiscali & M & M,I,D & M,I,D & M,D,E & \\
\hline Kinexia & n.a. & & & & & Txt & & M & M & & \\
\hline Kme & M,D & $\mathrm{M}, \mathrm{D}, \mathrm{E}$ & M,D & M & & Uni Land & $\mathrm{D}$ & $\mathrm{D}$ & $\mathrm{M}, \mathrm{E}$ & & M \\
\hline Krenergy & $\mathrm{M}, \mathrm{D}, \mathrm{E}$ & $\mathrm{M}, \mathrm{I}, \mathrm{D}, \mathrm{E}$ & $\mathrm{I}, \mathrm{E}$ & M,I,E & & Zucchi & & M,I,D & M,I,D & M & M,I \\
\hline
\end{tabular}

Description: $\mathrm{M}$ = management changes; $\mathrm{I}$ = divestment; $\mathrm{D}$ = debt restructuring; $\mathrm{E}$ = equity issuance; $\mathrm{n} . \mathrm{a}$. = not available. 
into advances for future capital increases, the renegotiation of expired debt with suppliers, new financing from banks, changes in the interest rate and the deferral of its payment. Equity issuance mostly included the issuing of new shares and advances for future capital increases.

It can clearly be seen that firms use a series of measures to find a way out of the crisis. $22.2 \%$ of firms show in their Management Commentary only one type of measure. In the other cases combinations of different types of intervention are proposed; $15.3 \%$ use two types, $19.4 \%$ three and $23.6 \%$ all four types. There were also many cases in which it was not possible to identify any type of restructuring measures. $19.4 \%$ of firms do not officially show any proposal that can be included according to the criteria presented in the previous section.

Considering that managers proposed different types of restructuring, it is not immediately detectable what their preference order is. The data shown in Table 2 have therefore been re-elaborated to give a general outline of the preferences expressed by managers on the basis of the following criteria: (a) preference is attributed to the restructuring measure that was chosen first; and (b) for the measures which were proposed in the same year, the preference is given to those that appeared the most number of years in the Management Commentary between 2007 and 2011.

The results of the analysis are shown in Table 3. The choice fell primarily on general management measures. These were often accompanied by other types of measures; firstly, debt restructuring, divestment of assets and lastly, the issuing of new shares. In second place, the choice fell on debt restructuring, then on an increase in capital and lastly divestment of assets. In a very limited number of cases, there are also third and fourth choices.

Table 3. Order of preference of restructuring measures

\begin{tabular}{lcccccccc}
\hline & \multicolumn{2}{c}{ Management changes } & \multicolumn{2}{c}{ Divestment } & \multicolumn{2}{c}{ Debt structuring } & \multicolumn{2}{c}{ Equity issuance } \\
\hline First choice & N. & $\%$ & N. & $\%$ & N. & $\%$ & N. & $\%$ \\
Second choice & 53 & $55.8 \%$ & 11 & $14.3 \%$ & 15 & $19.5 \%$ & 8 & $10.4 \%$ \\
Third choice & 3 & $13.2 \%$ & 7 & $18.4 \%$ & 16 & $42.1 \%$ & 10 & $26.3 \%$ \\
Fourth choice & 1 & $12 \%$ & 5 & $20 \%$ & 5 & $20 \%$ & 12 & $48 \%$ \\
\hline
\end{tabular}

The cases in which information about restructuring was not available in the Management Commentary were not included in Table 3 . These cases represent quite a significant proportion of the firms in the sample. As mentioned above, $19.4 \%$ of the firms did not mention clearly the need for restructuring.

In order to explore the reasons for the choices made by managers, this study has grouped the responses for solving the crises as regards the "first choice" into two groups: the responses that involved assets (Assets side) and those that occur exclusively or non-exclusively on capital structure (Debt \& Equity side). In the first group, we included responses concerning management changes and/or divestment; there are thirty nine firms in the sample that meet this criterion. The second group, of eighteen firms, includes the remaining kinds of responses.

Table 4. Predictor variables and logistic regression results

\begin{tabular}{|c|c|c|c|c|}
\hline & Estimate & Std Error & $\mathrm{z}$ value & $\operatorname{Pr}(>|z|)$ \\
\hline (Intercept) & -2.7850 & 1.6405 & -1.698 & 0.0896 \\
\hline EBITDA margin & 3.4713 & 2.3208 & 1.496 & 0.1347 \\
\hline Return on assets (ROA) & -9.5761 & 5.4505 & -1.757 & $0.0789 *$ \\
\hline Return on investment (ROI) & -2.6289 & 1.4924 & -1.761 & $0.0782 *$ \\
\hline Return on sales (ROS) & 0.4955 & 0.4830 & 1.026 & 0.3049 \\
\hline Equity to assets & 1.5603 & 2.7540 & 0.567 & 0.5710 \\
\hline Debt to assets & 4.0775 & 2.6596 & 1.533 & 0.1252 \\
\hline Current ratio & -0.5293 & 0.7335 & -0.722 & 0.4705 \\
\hline
\end{tabular}

Notes: * Significant at the 0.10 level (two-tailed). 
For the selected average financial ratios, as predictors of the logistic regression, Table 4 shows the predictor variables and the logistic regression results based on the model (1) described in section four.

The most significant predictor variables are Return on assets (ROA) and Return on investment (ROI). The ratios are commonly used as proxies of profitability although they are "far from perfect" (Fama \& French, 2002). More specifically, the negative coefficient for ROA and ROI suggests that the probability of having a "Debt \& Equity side" response $(\mathrm{Y}=1)$ decreases as the values of these variables increase. The other variables do not have a sufficient explanatory power to clarify the type of responses.

This result is consistent with the POT. The POT assumes that profitable firms have a tendency to finance its investment firstly through internal funds, then the issuing of debt and finally the issuing of shares. As addressed by several studies (just to name a few: Myers, 1984; Myers \& Majluf, 1984; Titman \& Wessels, 1988; Baskin, 1989; Allen, 1993; Fama \& French, 2002; Tong \& Green, 2005), the negative correlation between profitability and leverage is an important factor that validates the theory. Accordingly, on the basis of the sample examined and the methodology adopted in the present work, this paper found a negative association between external financing decisions and profitability.

\section{Summery and Conclusion}

The global economic crisis offers researchers the opportunity to analyse the decisions adopted by firms to overcome the difficulties they are facing. The main research question of the present work has been to see whether there exists an order of preference for the restructuring measures adopted by firms listed on the Italian Stock Exchange and to explore the reasons for choosing the types of restructuring measures. The sample under examination was made up of 72 firms (about a third of Italian listed companies) which, between 2007 and 2011, showed a negative "net income from continuing operations" for at least three years. The firms that were selected for the sample were in economic distress. Firms which were not only in economic distress, but also in financial distress were not excluded from the sample.

Unlike previous empirical studies, the present paper adopted a methodology that analysed the content of Management Commentary. The analysis of this report enabled us to highlight the plans, whether completed or not, that the managers intended to implement and therefore identify the managers' preferences. From this empirical research it emerges that restructuring measures are often proposed in a combined manner. Faced with a crisis, managers experiment with various solutions at the same time in the attempt to re-establish an economic equilibrium in the firm: general management changes; divestment of current and non-current assets; debt restructuring and the issuing of new shares. Although firms propose more than one solution at a time, priority seems to be given to management changes. The renegotiation of debt and issuing of new shares seem to be of secondary importance, though debt renegotiation tends to be preferred to the issuing of new shares.

In order to investigate the reasons for choosing one type of restructuring rather than another the paper analyzed the relationship between the type of choices (grouped into the "Assets side" responses and the "Debt \& Equity side" responses) and a set of financial ratios of the selected firms based on the logistic regression model. The regression results show that the probability of having a "Debt \& Equity side" response to the crises decreases as the values of the predictor variables Return on assets (ROA) and Return on investment (ROI) increase. The negative association between external financing decisions and profitability, measured approximately by ROA and ROI, is consistent with the POT. As previous research underlined, the negative relationship between profitability and leverage support the POT since the theory postulates that profitable firms prefer to finance new investments firstly through internal funds, then by the issuing of debt and finally with new shares.

The results of this paper have two main implications. First, the analysis of the choices relating to crises resolution measures proposed by managers provides a better understanding of the financial and investment policies of firms under economic distress. Information on the corporate policy regarding the capital structure and general management changes allows investors, lenders and other stakeholders to improve their decision making process in order to protect the value of their investments. Due to the high percentage of shares held by the public, this issue is especially relevant for listed firms that are in serious economic difficulties. Second, the examination of the choices regarding the restructuring measures can also be useful for Regulators in order to adopt and/or amend the rules for rescuing and restructuring firms in difficulty (e.g., financial support to firms and unemployment benefits).

This study has however some limitations. First, as for any qualitative estimate, there is inevitably a certain margin of error by examining the Management Commentary due to the analyst's judgment. Second, although the study analyzed approximately a third of Italian listed companies, the research is restricted by sample size. Third, the paper did not investigate the effects of the responses to the crisis on the firms' performances since the 
consequences of the restructuring will be revealed in a future time period. Regarding this limitation, future research may explore the correlation between the responses to the crisis and the firms' performances.

\section{References}

Al Manaseer, M. F., Gonis, E., Al-Hindawi, R. M., \& Sartawi I. I. (2011). Testing the Pecking Order and the Target Models of capital structure: evidence from UK. European Journal of Economics, Finance and Administrative Sciences, 41, 84-96.

Allen, D. E. (1993). The pecking order hypothesis: Australian evidence. Applied Financial Economics, 3(2), 101-112. http://dx.doi.org/10.1080/758532828

Altman, E. (1968). Financial ratios, discriminant analysis and the prediction of corporate bankruptcy. Journal of Finance, 23, 589-609. http://dx.doi.org/10.1111/j.1540-6261.1968.tb00843.x

Andrade, G., \& Kaplan, S. N. (1998). How costly is financial (not economic) distress? Evidence from highly leveraged transactions that became distressed. Journal of Finance, 53(5), 1443-1493. http://dx.doi.org/10.1111/0022-1082.00062

Balcaen, S., Manigart, S., Buyze, J., \& Ooghe, H. (2012). Firm exit after distress: differentiating between bankruptcy, voluntary liquidation and M\&A. Small Business Economics, 39(4), 949-975. http://dx.doi.org/10.1007/s11187-011-9342-7

Banca d'Italia. (2013). Bollettino economico, Appendice statistica n.71. Roma, Italia: Banca d'Italia.

Baskin, J. (1989). An empirical investigation of the Pecking Order Hypothesis. Financial Management, 18(1), 26-35. http://dx.doi.org/10.2307/3665695

Bauweraerts, J., \& Colot, O. (2012). Pecking-Order or static trade-off theory in family firms? Evidence from Belgium. International Business Research, 5(11), 1-11. http://dx.doi.org/10.5539/ibr.v5n11p1

Beaver, W. H. (1966). Financial ratios as predictors of failure. Journal of Accounting Research, supplement, 4(3), 71-111.

Bharat, S. T., Pasquariello, P., \& Wu, G. (2009). Does asymmetric information drive capital structure decisions? The Review of Financial Studies, 22(8), 3211-3243. http://dx.doi.org/10.1093/rfs/hhn076

Bigelli, M., Mengoli, S., \& Sandri, S. (2001). I fattori determinanti la struttura finanziaria delle imprese italiane: una verifica empirica sulle società quotate. Finanza, Marketing e Produzione, 19(4), 71-93.

Borsa Italiana. (2013). Andamento indici azionari, 15 marzo 2013. Retrieved from http://www.borsaitaliana.it/... /andamentoindici2013_pdf.htm

Boushey, H., \& Weller, C. E., (2008). Has growing inequality contributed to rising household economic distress? Review of Political Economy, 20(1), 1-22. http://dx.doi.org/10.1080/09538250701661764

Bozzolan, S., Trombetta, M., \& Beretta, S. (2009). Forward looking disclosure and analysts' forecasts: a study of cross-listed European Firms. European Accounting Review, 18(3), 435-473. http://dx.doi.org/10.1080/09638180802627779

Brockett, P. L., Golden, L. L., Jang, J., \& Yang, C. (2006). A comparison of neural network, statistical methods, and variable choice for life insurers' financial distress prediction. The Journal of Risk and Insurance, 73(3), 397-419. http://dx.doi.org/10.1111/j.1539-6975.2006.00181.x

Campbell, J. Y., Hilscher, J., \& Szilagyi, J. (2010). Predicting financial distress and the performance of distressed stocks. Retrieved from http://kuznets.fas.harvard.edu/ campbell/papers/..._JOIM.pdf

Chirinko, R. S., \& Singha, A. R. (2000), Testing static trade-off against pecking order models of capital structure: a critical comment. Journal of Financial Economics, 58, 417-425. http://dx.doi.org/10.1016/S0304-405X(00)00078-7

Deloitte. (2008). Assets held for sale and discontinued operations. A guide to IFRS 5: an IAS Plus guide. from http://www.iasplus.com/en/publications/global/guides/pub1923.

Dezzani, F., Biancone, P. P., \& Busso, D. (2012). IAS/IFRS. Milanofiori Assago, ITA: Wolters Kluwer Italia.

Etheridge, H. L., \& Sriram, R. S. (1997). A Comparison of the relative costs of financial distress models: artificial neural networks, logit and multivariate discriminant analysis. Intelligent Systems in Accounting, Finance and Management, 6, 235-248.

Fama, E. F., \& French, K. R. (2002). Testing trade-off and pecking order predictions about dividends and debt. 
The Review of Financial Studies, 15(1), 1-33. http://dx.doi.org/10.1093/rfs/15.1.1

Fanning, K. M., \& Cogger, K. O. (1994). A Comparative analysis of artificial neural networks using financial distress prediction. Intelligent Systems in Accounting, Finance and Management, 3, 241-252.

Frank, M. Z., \& Goyal, V. K. (2003). Testing the pecking order theory of capital structure. Journal of Financial Economics, 67, 217-248. http://dx.doi.org/10.1016/S0304-405X(02)00252-0

Hillegeist, S. A., Keating, E. K., Cram, D. P., \& Lundstedt, K. G. (2004). Assessing the probability of bankruptcy. Review of Accounting Studies, 9, 5-34. http://dx.doi.org/10.1023/B:RAST.0000013627.90884.b7

Hotchkiss, E. S., John, K., Mooradian, R. M., \& Thorburnk, K. S. (2008). Bankruptcy and the resolution of financial distress. In B. Espen Eckbo (Ed.), Handbook of Empirical Corporate Finance (Vol. 2). Elsevier B.V. Retrieved from http://mba.tuck.dartmouth.edu/.../Ch14-N53090.pdf

IASB. (2010). IFRS Practice Statement, Management Commentary: A framework for presentation. London, UK: IFRS Foundation.

Jiang, K., \& Wang, S. (2009). Firms in economic distress: survival strategies and economic factors, 1-40. Retrieved from http://ssrn.com/abstract=1465181

John, R., Lang, L. H. P., \& Netter, J. (1992). The voluntary restructuring of large firms in response to performance decline. The Journal of Finance, 47(3), 891-917. http://dx.doi.org/10.1111/j.1540-6261.1992.tb03999.x

Kahl, M. (2002). Economic distress, financial distress, and dynamic liquidation. The Journal of Finance, 57(1), 135-168. http://dx.doi.org/10.1111/1540-6261.00418

Kang, J. K., \& Shivdasani, A. (1997). Corporate restructuring during performance declines in Japan. Journal of Financial Economics, 46, 29-65. http://dx.doi.org/10.1016/S0304-405X(97)00024-X

Leary, M. T., \& Roberts, M. R. (2005). Do firms rebalance their capital structures? Journal of Finance, 60(6), 2575-2619. http://dx.doi.org/10.1111/j.1540-6261.2005.00811.x

Lemmon, M. L., \& Zender, J. F. (2010). Debt capacity and tests of capital structure theories. Journal of Financial and Quantitative Analysis, 45(5), 1161-1187. http://dx.doi.org/10.1017/S0022109010000499

Lemmon, M., Ma, Y. Y., \& Tashjian, E. (2009). Survival of the fittest? Financial and economic distress and restructuring outcomes in Chapter 11. Retrieved from http://ssrn.com/abstract=1325562

Liang, H. Y., \& Bathala, C. (2009). Tradeoff or Pecking Order: capital structure policy suitable for financially distressed firms. The IUP Journal of Applied Finance, 15(10), 5-18.

Mazen, G. (2012). French firm's financing choices: towards a reconciliation of the static trade-off theory and the Pecking Order Theory? International Journal of Financial Research, 3(1), 57-72. http://dx.doi.org/10.5430/ijfr.v3n1p57

Mediobanca. (2008). Dati cumulativi di 2020 società italiane. Milano, Italia: Mediobanca-Ufficio Studi.

Mediobanca. (2012). Dati cumulativi di 2031 società italiane. Milano, Italia: Mediobanca-Ufficio Studi.

Menicucci, E. (2013). The determinants of forward-looking information in Management Commentary: evidence from Italian listed companies. International Business Research, 6(5), 30-44. http://dx.doi.org/10.5539/ibr.v6n5p30

Mns. (2012). Retrieved November 20, 2012, from http://money.msn.com

Molina, C. A., \& Preve, L. A. (2009). Trade receivables policy of distressed firms and its effect on the costs of financial distress. Financial Management, 38(3), 663-686. http://dx.doi.org/10.1111/j.1755-053X.2009.01051.x

Myers, S. C. (1984). The capital structure puzzle. Journal of Finance, 39, 575-592. http://dx.doi.org/10.2307/2327916

Myers, S. C., \& Majluf, N. (1984). Corporate financing and investment decisions when firms have information that investors do not have. Journal of Financial Economics, 13(2), 187-221. http://dx.doi.org/10.1016/0304-405X(84)90023-0

Opler, T. C., \& Titman, S. (1994). Financial distress and corporate performance. The Journal of Finance, 49(3), 1015-1040. http://dx.doi.org/10.1111/j.1540-6261.1994.tb00086.x

Panno, A. (2003). An empirical investigation on the determinants of capital structure: the UK and Italian 
experience. Applied Financial Economics, 13, 97-112. http://dx.doi.org/10.1080/09603100210100882

Sheikhi, M., Fallah, S. M., \& Sheikhi, Z. (2012). Financial distress prediction using distress score as a predictor. International Journal of Business \& Management, 7(1), 169-181.

Shyam, S. L., \& Myers, S. C. (1999). Testing static tradeoff against pecking order models of capital Structure. Journal of Financial Economics, 51, 219-244.

Song, J. (2012). Economic distress, labor market reforms, and dualism in Japan and Korea. Governance: An International Journal of Policy, Administration, and Institutions, 25(3), 415-438. http://dx.doi.org/10.1111/j.1468-0491.2012.01566.x

Southall, H., \& Gilbert, D. (1996). A good time to wed?: marriage and economic distress in England and Wales, 1839-1914. Economic History Review, 49(1), 35-57. http://dx.doi.org/10.2307/2598447

Titman, S., \& Wessels, R. (1988). The determinants of capital structure choice. Journal of Finance, 43(1), 1-19. http://dx.doi.org/10.1111/j.1540-6261.1988.tb02585.x

Tong, G., \& Green, C. J. (2005). Pecking order or trade-off hypothesis? Evidence on the capital structure of Chinese companies. Applied Economics, 37(19), 2179-2189. http://dx.doi.org/10.1080/00036840500319873

Ward, T. J. (1994). An empirical study of the incremental predictive ability of Beaver's naive operating flow measure using four state ordinal models of financial distress. Journal of Business Finance \& Accounting, 21(4), 547-561. http://dx.doi.org/10.1111/j.1468-5957.1994.tb00335.x

Ward, T. J., \& Foster, B. P. (1997). A note on selecting a response measure for financial distress. Journal of Business Finance \& Accounting, 24(6), 869-879. http://dx.doi.org/10.1111/1468-5957.00138

Wu, D. D., Liang, L., \& Yang, Z. (2008). Analyzing the financial distress of Chinese public companies using probabilistic neural networks and multivariate discriminate analysis. Socio-Economic Planning Sciences, 42(3), 206-220. http://dx.doi.org/10.1016/j.seps.2006.11.002

\section{Copyrights}

Copyright for this article is retained by the author(s), with first publication rights granted to the journal.

This is an open-access article distributed under the terms and conditions of the Creative Commons Attribution license (http://creativecommons.org/licenses/by/3.0/). 